\title{
Aktuell film og litteratur
}

\section{Ny film: \\ C hristian G rønning: \\ Når livet bliver \\ for langt - en \\ undervisnings- \\ film til debatt}

Odense: 2004 (27 min.)

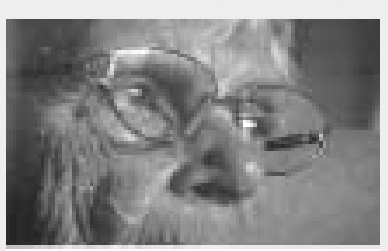

NAR LWET ITENER FOR LAKIII

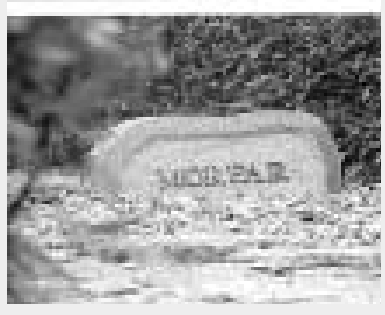

En VHS-kopi koster DKK 300 + mva. og kan bestilles hos Radix Medier:

Christian Grønning salg@radixmedier.dk
"D et var helt obegribelig at min mor hadde begået selvmord."

" H vorfor skulle jeg sidde her og være så ked af det? Så var det da bedre, at jeg gjorde en lang sag kort."

Slik starter en ny dansk film om selvmord blant eldre mennesker. En gammel kvinne orket ikke å leve lenger, og datteren forteller om hvordan moren hadde det etter at hun ble enke, og etter hvert ble alvorlig deprimert. Vi møter også en gammel kvinne som selv har hatt alvorlige selvmordstanker. Hun utdyper hvordan hun opplevde å leve helt alene uten daglig kontakt med andre og uten å bli tatt på alvor da hun ba om hjelp fra helsevesenet for sine selvmordstanker. De to kvinnene snakker vekselvis gjennom store deler av filmen, på en naturlig og ubesværet måte, om hvordan depressive tanker kan ta over og styre tilværelsen. De får på en troverdig måte formidlet hvordan det er å være gammel, oppleve tap og dermed miste livslysten. Samtidig skaper de en kontrast: Datteren snakker som pårørende og etterlatt og sitter igjen med en stor sorg, mens den eldre kvinnen har fått hjelp til å velge å leve videre og har fătt en meningsfylt tilværelse.
Gjennom filmen formidler fagpersoner fakta om høye selvmordstall blant eldre i Danmark og samfunnets syn på de eldre: Det har i de senere årene vært en nedgang $i$ antall selvmord blant alle aldersgrupper bortsett fra blant de eldste. Hver uke tar fire personer over 65 år sitt eget liv i Danmark. Intervjuer med eldre som har overlevd selvmordsfors $\varnothing \mathrm{k}$, viser at mange eldre opplever tilværelsen som håpløs, og at det ikke er hjelp å få. De føler seg ensomme og deprimerte. Eldre regnes ikke med i samfunnet. Ingen har bruk for dem lenger. Selvmordsproblemet feies under teppet: "Hvorfor forhindre gamle mennesker i at begå selvmord? De skal alligevel snart $\mathrm{d} \varnothing-$ og deres selvmord betyder kun en besparelse for samfundet! "

Dette er en sterk film som berører oss, og som forhåpentligvis vil vekke debatt også her i landet. Hva slags samfunn $\varnothing$ nsker vi til syvende og sist å skape? Filmen anbefales alle som arbeider med eldre mennesker, og samfunnsplanleggere.

Filmen har mottatt en pris av Danmarks radio som beste TV-hovedoppgave på Institut for Journalistik ved Syddansk Universitet i Odense.

\section{Kirsti Amundsen}

\section{Jorit Tellervo (red.):}

\section{Selvmord blandt gamle mennesker - myter, viden og forebyggelse.}

København: Nyt Nordisk Forlag Arnold Busck, 2004. 238 s., ill. Pris: DKK 249. ISBN 87-17-03715-8

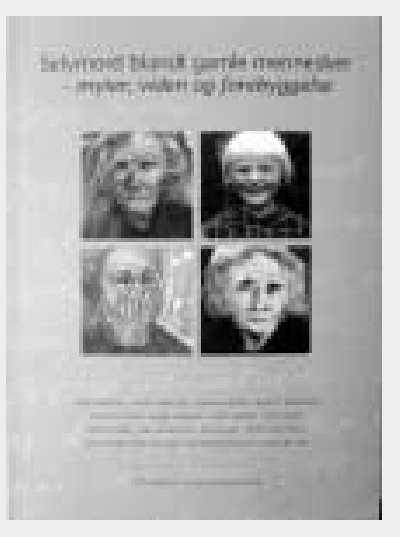

I innledningen gir redaktøren følgende begrunnelse for utgivelsen: I mange vestlige land (også i Norge) er selvmordshyppigheten st $\varnothing$ rst i de eldste aldersgrupper. Likevel har medier og forskere hovedsakelig konsentrert seg om unge mennesker. Mangelen på oppmerksomhet kan støtte oppfatningen om at selvmord ikke angår gamle. Det medvirker til at omverdenen ikke er forberedt på å fange opp signaler om selvmord fra et gammelt menneske.

Boken er utgitt med st $\varnothing$ tte fra Sundhedsstyrelsen i Danmark. Det er en antologi med bidrag fra en rekke forfattere med ulik bakgrunn: Forskere, leger, psykologer, sykepleiere, filosof og teologer gir sammen en bred og spennende gjennomgang av dette store og vanskelige temaet. Forfatterne presenterer den forskningsbaserte kunnskapen som finnes, men de formidler også viktig erfaringsbasert viten fra sine respektive faglige ståsteder. Det er også en rekke intervjuer med mennesker som har personlige erfaringer - det kan være pårørende/etterlatte, helsepersonell eller eldre som selv har gjort selvmordsfors $\varnothing \mathrm{k}$.
Disse kapitlene formidler en form for kunnskap til forståelse, og de kompletterer på en viktig måte faktakunnskapen i boken. Nydelige og uttrykksfulle illustrasjoner er utført av bokens redakt $\varnothing r$, Jorit Tellervo, som har bakgrunn som sykepleier og bildende kunstner.

Veksling mellom teoretisk pregede kapitler og intervjuer gjør dette til lett og fascinerende lesning. Dansk språkdrakt burde ikke by på problemer for nordmenn.

Her tar man opp et viktig tema som på mange måter er tabu også her i landet. Kunnskap og innsikt i en kompleks problematikk formidles på en utmerket måte. Jeg vil anbefale boken til alle med interesse for dette temaet, uavhengig av faglig bakgrunn.

\section{Ildri Kjølseth}

D enne bokanmeldelsen ble første gang trykket i Tidsskrift for D en norske lægeforening 2005; 125: 320. 


\section{Solveig Bøhle: \\ Å ville døden \\ sterkere enn livet. \\ Om depresjon, selvmord og etter- lattes situasjon.}

G yldendal akademisk 2004. 181 s. Pris: 199 kr. ISBN 82-05-33726-8

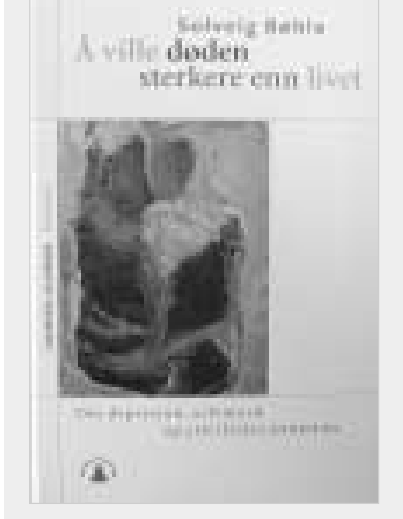

A rnt-0 ve Eikeland:

Til den ytterste grind. Selvmord i et arktisk samfunn

Kautokeino: Sámi Instituhtta, N ordisk Samisk Institutt, 2003 (Diedut 2003;1)

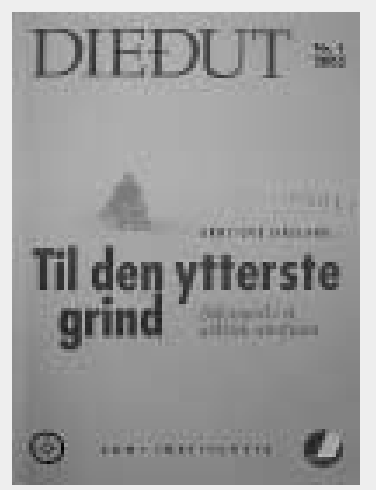

Boken kan bestilles fra: SÁ M I IN STIT U HTTA - N ordisk Samisk Institutt, +47 78488000 , info@nsi.no
Dette er en bok som kan leses av både leg og Iærd med utbytte, - det i seg selv er en bragd. Forfatteren er en erfaren journalist og har val gt en fremstillingsform i denne boken som gjør at her kan de aller fleste lesere finne noe av betydning. H er er vekselvis intervjuer med mennesker som har forsøkt å ta sitt liv, pårørende, etterlatte, samt spesialister innen flere rel evante fagområder. Ingen kapitler er på mer enn 10 sider, noe som gjør at man hele tiden har lyst til å bare lese "litt til"; og så er hele boken lest!

$\mathrm{N}$ år jeg leser den som fagperson er det de selvopplevde beretningene som taler sterkest til meg. $\mathrm{H}$ er er de nære og autentiske beretninger om smerten ved selvmord og vår tilkortkommenhet i å forstå i tide det som er i ferd med å skje. Fremstillingen bærer ikke preg av etterpåklokskap, men den legger vekt på den ettertenksomme refleksjon. Historiene representerer en nærhet og intensitet som bare de som har egenopplevelse kan formidle, og den taler til hjertet i oss. Selv om boken omtaler et trist tema, så makter den å formidle håp. I så måte er det historien "Jeg var ikke lenger alene", en historie om den rusmisbrukende og deprimerte unggutten Erik, som er tydeligst. H er er den akademiske distanse på en befriende måte fraværende.

Intervjuene med et utval g fagpersoner er også informative og tankevekkende. Behandlingsperspektivet belyses både fra et psykoterapeutisk og biomedisinsk perspektiv. Den svenske hjerneforskeren A nnica Dahlstrøm som er intervjuet i kapittelet "Sjelens verktøy", et kapittel som primært handler om hjernens signalstoffer, makter til å med å løfte inn synspunkter på likestilling i denne sammenheng som kan virke provoserende. Som ellers i boken er heller ikke disse kapitlene lange eller for kompliserte, selv om de nok krever en annen forståelse. A t tema som homofili og diagnosen A DH D også bringes fram virker som en understrekning av at underkommuniserte tema skal fram i lyset.

Boken er ment for brede grupper lesere. Den er god folkeopplysning og kan med fordel leses av fagfolk. Som klassisk lærebok i suicidologi har den åpenbare begrensninger, men den var vel heller ikke ment som slik. Det er etter min mening de nære og ekte beretningene som gjør boken spesielt leseverdig.

Dag Willy Tallaksen
Boken "Til den ytterste grind" er basert på forfatterens hovedfagsoppgave i fil osofi, som ble fullført i desember 1999 ved U niversitetet i Tromsø. $M$ ålet med boken er å si noe allment om den arktiske selvmordsproblematikken ved å ta utgangspunkt i et konkret sted, som i boken blir omtalt som Bygda. A rnt-O ve Eikeland har et spesielt utgangspunkt med hen syn til å skulle skrive denne boken. $\mathrm{H}$ an kommer selv fra den aktuelle Bygda hvor 30 personer har tatt sitt eget liv siden 1987, og som han skriver i innledningen: "D erfor oppfatter jeg det som min oppgave som local boy å være med på å lodde dybden i og omkring problematikken med de høye selvmordstallene på denne plassen. Dybden skal derfor loddes med utgangspunkt i lokale stemmer og fortellinger, deriblant min egen stemme."

Boken består av to hoveddeler, en beskrivende og en analytisk. Den beskrivende delen har A rntO ve Eikeland kalt Bygda, og den analytiske delen for Selvet. I den første delen blir leseren ført inn i Bygdas kulturhistoriske kontekst gjennom tre "landskapsbeskrivelser", beskrivelse av landskapet i kommunen, redegjørelse for selvmordsproblematikken på stedet, samt beskrivelse av den historiske og sosiale konteksten. Disse tre beskrivelsene danner grunnlaget for analysen, hvor selvmordsproblematikken blir diskutert ut fra moralske og etiske begreper.

Boken er et prosjekt som ble "født på basis av stemninger som forundring og angst, og som har resultert i omsorg". Den faglige målsetning har vært å finne teoretiske ståsteder som kan være med på å skape en økt forståelse for selvmordsproblematikkens omfang og kompleksitet. I boken er det de lokale fortellinger og stemmer som danner grunnlag for forskning omkring problematikken, hvor enkeltpersoner kommer frem med sin forståelse og fortolkning av problemet. A rnt-O ve Eikel and anser ikke selvmord først og fremst som et teoretisk problem, men som et praktisk problem. "H va som er sel vmordets "røtter", er mindre viktig enn spørsmålet om hvordan det skal kunne forhindres. Selvmordsproblematikken blir slik sett oppfattet som en oppgave, og ikke Bygdas skjebne."

"Til den ytterste grind" gir en grundig innføring i utviklingen og fortolkningen av selvmordsproblematikken i en samisk bygd. Boken understreker betydningen av å ha inngående kunnskap om lokal kulturhistorie og samfunnsutvikling i forståelsen av problemet. Selv om boken tar utgangspunktet i selvmordsproblematikken i en enkelt bygd, så har den allmenngyldig relevans. For oss som klinikere har boken brakt inn nye dimensjoner i den kliniske hverdagen som ofte avgrenses til individ, kausal itet og patologi. A rnt-O ve Eikel and har absolutt lykkes med å skrive en bok som bryter med faggrensene, og som inviterer til en bredere dialog. $0 \mathrm{~g}$ som han selv viser til i boken " Der det ingen dialog er, er det heller intet håp for helbredelse" (Kierkegaard, S.).

G unn H eatta og A nne C. Silviken, Samisk U ngdomspsykiatrisk Team Karasjok 